\title{
MEDIA KOMUNIKASI MASSA IKLAN ROKOK SERTA DISTRIBUSI MINAT BELI KONSUMEN ROKOK KOTA MEDAN
}

\author{
Zata Ismah, Ikhwan, Gusti Anom Pramulia, Tasya Manik, Hilda Vilia, Dytha Taniya Abdika, Enno \\ Tubagus Mafira, Zikra Maya Ulfa, Fauziah Fitri Tambunan \\ Fakultas Kesehatan Masyarakat, Universitas Islam Negeri Sumatera Utara \\ Zataismah@uinsu.ac.id
}

\begin{abstract}
ABSTRAK
Pemerintah kota medan telah mengatur pembatasan iklan rokok melalui Perda No 3 Tahun 2014 tentang kawasan tanpa rokok, pembatasan terhadap iklan rokok terus dilakukan akan tetapi konsumsi rokok terus meningkat. Penelitian ini bertujuan untuk mengetahui gambaran paparan iklan rokok dan minat beli konsumen rokok pada perokok di kota medan. Penelitian ini merupakan penelitian survey cepat dengan analisis survey. Sampel penelitian adalah perokok sebanyak 210 sampel dengan alat pengumpulan data berupa instrument kuisioner yang diadopsi dari penelitian terdahulu. Kuesioner telah di uji kualitasnya melalui Uji Validitas dan Reliabilitas. Hasil Penelitian didapatkan mayoritas responden adalah laki laki, usia terbanyak 45-54 tahun dan mayoritas berpendidikan terakhir SMA. Rata-rata total paparan iklan rokok pada responden menunjukkan kategori sedang $(2.10 \mathrm{kali} / \mathrm{hari})$ dengan paparan frekuensi menunjukkan kategori sedang (2.08 kali/hari), paparan intensitas menunjukkan kategori sedang (2.63 kali/hari) dan paparan durasi menunjukkan kategori rendah (1.83 $\mathrm{kali} / \mathrm{hari})$. Rata-rata minat total pembelian rokok pada responden menunjukkan kategori sedang (2.22 kali/hari) dengan minat transaksional menunjukkan kategori rendah (1.75 kali/hari), minat referensial menunjukkan kategori rendah (1.85 kali/hari), minat preferensial menunjukkan kategori sedang (2.86 kali/hari) dan minat eksploratif menunjukkan kategori sedang (2.45 kali/hari). Rata-rata paparan iklan rokok pada responden menunjukkan kategori sedang dan rata rata minat pembelian rokok pada responden sedang.
\end{abstract}

Kata Kunci : Paparan iklan, rokok, minat beli

\begin{abstract}
The Medan city government has regulated restrictions on cigarette advertising through Perda No. 3/2014 on smoking-free areas, restrictions on cigarette advertising continue to be carried out but cigarette consumption continues to increase. This study aims to determine the description of cigarette advertisement exposure and cigarette consumer buying interest in smokers in the city of Medan. This research is a rapid survey research with survey analysis. The research sample was 210 smokers with a data collection tool in the form of a questionnaire that was adopted from previous research. The questionnaire has been tested for quality through validity and reliability tests. The results showed that the majority of respondents were male, most aged 45-54 years and the majority had high school education. The average total exposure to cigarette advertisements in respondents was in the moderate category (2.10 times / day) with frequency exposure showing the moderate category (2.08 times / day), the intensity exposure showed the moderate category (2.63 times / day) and the duration of exposure was the low category (1.83 times / day). The average total interest in buying cigarettes in respondents shows a moderate category (2.22 times / day) with transactional interest showing a low category (1.75 times / day), referential interest shows a low category (1.85 times / day), preferential interest shows a moderate category (2.86 times / day) and explorative interest showed moderate category (2.45 times / day). The average exposure to cigarette advertisements in the respondents showed a moderate category and the average interest in buying cigarettes in the respondents was moderate.
\end{abstract}

Keywords : Advertising exposure, cigarettes, buying interest 


\section{PENDAHULUAN}

Data WHO menunjukkan terdapat sekitar satu miliar perokok atau sekitar sepertujuh dari populasi total dunia. Prevalensi merokok pada orang dewasa secara global selama priode 5 tahun belakang masih belum menunjukkan penurunan sedangkan prevalensi merokok pada remaja secara global pada rentang usia 10-19 tahun meningkat dari 7,2\% di tahun 2013 menjadi 9,1 \% pada tahun 2018 mengalami peningkatan sebesar 20\% (WHO, 2018). Indonesia menempati peringkat ketiga dengan prevalensi merokok sebesar 29\% secara nasional setelah cina dan india. (WHO dalam TCSC IAKMI, 2020)

Berdasarkan laporan Riset Kesehatan Dasar (2018) prevalensi perokok usia 15 tahun ke atas di Indonesia sebesar 33,8\%. Dimana sebanyak 62,9\% adalah laki laki. Konsumsi rokok pada perokok usia 10-18 tahun juga mengalami peningkatan sebesar 1,9\% dalam jangka waktu 5 tahun (2013-2018), bahkan anak seorang anak sudah mulai mencicipi rokok sejak usia sekolah dasar. (Atlas Tembakau dalam TSC IAKMI, 2020)

Penelitian Bakti (2019) menunjukkan prevalensi merokok setiap hari di kota medan sebesar 55,2\% dan merokok sekali kali sebesar 14,3\% lebih tinggi dibandingkan angka nasional yaitu 54\% pada tahun 2016. Prevalensi merokok setiap hari pada pria sebesar 58,40\%, dan $15,13 \%$ yang sekali kali merokok, angka ini dibawah angka nasional sebesar $66 \%$ pada tahun 2013. Sementara pada wanita sebesar 7,1\% angka ini termasuk tinggi karena diatas angka nasional sebesar 6,7\% pada tahun 2013. (Bakti, 2019)

Rokok berbahaya bagi kesehatan, badan kesehatan dunia (WHO) menunjukkan konsumsi tembakau bertanggung jawab atas sekitar 17 persen dari hampir 18 juta kematian akibat penyakit kardiovaskular secara global setiap tahunnya. Sebatang rokok mengandung lebih dari 4000 jenis senyawa kimia, 400 zat berbahaya, 43 zat penyebab kanker (karsinogenik), CO (Carbonmonoksida) gas beracun yang dapat menurunkan kadar oksigen pada darah, kandungan Tar yang menyebabkan kanker dan Nikotin yang menyebabkan kecanduan (adiksi) (P2PTM Kemenkes, 2018).

Masih banyak golongan yang menganggap bahwa rokok tidak berbahaya bagi kesehatan dan sudah menjadi kebutuhan yang tidak dapat tergantikan. Tercatat hingga tahun 2018 kebutuhan akan rokok terus meningkat mencapai 332,38 milyar batang. Angka tersebut sudah jauh melampui target pada peta jalan produksi tembakau tahun 2015-2020 (Kementrian Perindustrian, 2020). Pada sektor ekonomi cukai hasil tembakau (CHT) menjadi salah satu pendapatan negara yang paling besar, pada tahun 2018 pendapatan negara dari cukai hasil tembakau mencapai Rp 159,6 triliun melebihi target APBN senilai Rp 155,4 triliun dan pada 
tahun 2019 cukai hasil tembakau mecapai 213,27 triliun dari yang ditargetkan pada APBN sebesar Rp 208,8 triliun. (Kementrian Keuangan, 2019)

Tanpa melihat pro kontra rokok tersebut, pemerintah sebenarnya telah banyak membuat regulasi untuk mengendalikan konsumsi rokok pada masyarakat. Berdasarkan Permenkes No 28 Tahun 2013 yang mengatur pembatasan iklan rokok di seluruh media cetak maupun elektronik. Permenkes tersebut juga mengatur untuk jadwal siaran iklan rokrok ditelevisi hanya pada pukul 21.30 hingga 05:00 pag dan untuk media teknologi informasi aksesnya hanya untuk usia diatas 18 tahun. (Permenkes No 28 Tahun 2013)

Pembatasan iklan rokok juga tercantum pada PP No 109 tahun 2012 tentang pengaman bahan yang mengandung zat adiktif berupa produk tembakau bagi kesehatan menyatakan bungkus rokok harus mencantumkan peringatan dalam bentuk tulisan atau gambar, minimal $10 \%$ dari total durasi iklan atau $15 \%$ dari total luas iklan. Peraturan ini juga menegaskan iklan tidak boleh mengambarkan wujud rokok, nama produk sebagai rokok, menyarankan rokok, menampilkan kalimat menyesatkan, menampilkan anak, remaja, tokoh kartun dan wanita hamil. Iklan rokok juga harus mencantumkan 18+ untuk usia yang pantas merokok. (PP No 109 Tahun 2012) Pemerintah kota medan juga megatur pembatasan iklan rokok tersebut melalui Perda No 3 Tahun 2014 tentang Kawasan tanpa rokok.

Pembatasan iklan rokok berdasarkan peraturan tersebut membuat produsen rokok terus gencar dalam mengiklankan rokoknya melalui media cetak maupun elektronik agar konsumen terpapar oleh iklan rokok. Gencarnya iklan rokok dibuktikan dengan total belanja iklan rokok yang mencapai $\operatorname{Rp~7,2~triliun~dengan~pertumbuhan~} 24$ persen pada tahun 2019, paparan iklan inilah yang mempengaruhi minat konsumen untuk menggunakan dan menbeli rokok. (www.nielsen.com, 2020).

Berdasarkan uraian diatas maka peneliti tertarik untuk melakukan penelitian dengan judul "Gambaran Paparan Iklan Rokok dan Minat Beli Konsumen Rokok Pada Perokok Di Kecamatan Medan Perjuangan Kota Medan”. Pemilihan kecamatan perjuangan sebagai lokasi penelitian karna diketahui berdasarkan penelitian yang pernah dilakukan Warahmah (2018) bahwa besarnya pengaruh dari slogan iklan rokok yang tertera pada bungkus rokok terhadap minat beli masyarakat kelurahan pahlawan kecamatan medan perjuangan mencapai $32,2 \%$. 


\section{METODE}

Penelitian ini menggunakan rancangan survey cepat (rapid survey). Penelitian dilakukan di 9 kelurahan pada kecamatan medan perjuangan kota medan. Penelitian dilaksanakan pada tanggal 25 Januari 2021 hingga tanggal 15 Februari 2021. Instrument dalam penelitian ini menggunakan instrument kuisioner yang diadopsi dari penelitian terdahulu milik Ridhwan Harleyandi Sudibyo dengan judul "Pengaruh Paparan Iklan Rokok terhadap Minat Beli Konsumen Rokok (Studi Kasus pada Mahasiswa Fakultas Ekonomi Universitas Islam Indonesia)” yang telah diuji validitas dan reliabilitasnya. Adapun pertanyaan dalam instrument ini terdiri dari 22 butir pertanyaan, 6 butir pertanyaan tentang data demografi, 9 butir pertanyaan tentang paparan iklan rokok (Frekuensi, intensitas dan durasi) dan 7 butir pertanyaan tentang minat pembelian (Minat transaksional, minat preferensial dan minat eksploratif.

Populasi penelitian adalah masyarakat yang bertempat tinggal di kecamatan Medan Perjuangan. Sedangkan sampel penelitian ini adalah masyarakat perokok yaitu sebanyak 210 sampel. Metode perhitungan sampel dilakukan dengan menggunakan pendekatan survei cepat WHO yaitu 30 cluster x 7 sampel dan menggunakan bantuan software C-Survey. Pengambilan sampel dilakukan dengan menggunakan dua metode yaitu metode cluster sampling dimana dari 9 kelurahan yang ada dihitung dan didapatkan 30 cluster dengan rincian Kelurahan Pandau hilir 2 cluster, Kelurahan Sei Kera Hulu 1 cluster, Kelurahan Sei Kera Hilir I 6 cluster, Kelurahan Sei Kera Hilir II 1 cluster, Kelurahan Sidorame Timur 2 cluster, Kelurahan Pahlawan 3 cluster, Kelurahan Sidorame Barat II 3 cluster, Kelurahan Sidorame Barat I 5 cluster, dan Kelurahan Tegal Rejo 7 cluster. Kemudian metode kedua menggunakan simple random sampling dengan masing-masing cluster terdiri dari 7 sampel. Sehingga didapatkan jumlah responden sebesar 210 sampel. Faktor Inklusi adalah penduduk tetap kecamatan medan perjuangan dengan prilaku merokok dan faktor ekslusi penduduk pendatang bukan penduduk tetap kecamatan medan perjuangan dan tidak beprilaku merokok.

Pengumpulan data dengan melakukan wawancara langsung menggunakan instrumen penelitian yaitu kuesioner yang diintegrasikan dengan google form secara online terdiri dari pertanyaan mengenai karakteristik responden, paparan iklan rokok dan minat beli rokok pada perokok di kecamatan medan perjuangan. Sebelum diteliti, responden terlebih dahulu menyetujui lembar informed consent. Analisis data menggunakan analisis univariat yang menggambarkan paparan iklan rokok dan minat beli rokok pada perokok di kecamatan medan perjuangan. Paparan iklan rokok dan minat beli rokok didapatkan dari kuesioner berupa 
demografi berupa umur, jenis kelamin, pendidikan terakhir dan data paparan iklan rokok dan minat beli rokok oleh perokok.

HASIL

Tabel 1.

Karakteristik Responden di Kecamatan Medan Perjuangan

\begin{tabular}{lccc}
\hline \multicolumn{1}{c}{ Variabel } & Frekuensi & Persentase & 95\%CI \\
\hline Jenis Kelamin & & & \\
\hline Laki-laki & 200 & 95.2 & $92.4-97.6$ \\
\hline Perempuan & 10 & 4.8 & $2.4-7.6$ \\
\hline Usia (Tahun) & 31 & 14.8 & $10.5-19.5$ \\
\hline $15-24$ & 43 & 20.5 & $15.2-26.2$ \\
\hline $25-34$ & 47 & 22.4 & $17.1-28.1$ \\
\hline $35-44$ & 48 & 22.9 & $17.1-28.6$ \\
\hline $45-54$ & 27 & 12.9 & $8.6-17.1$ \\
\hline $55-64$ & 13 & 6.2 & $0.0-1.4$ \\
\hline $65-74$ & 1 & 0.5 & $10.0-20.0$ \\
\hline $75-84$ & & & $51.4-65.2$ \\
\hline Pendidikan Terakhir & 31 & 14.8 & $13.3-23.8$ \\
\hline Tamat Perguruan Tinggi & 123 & 58.6 & $2.9-9.0$ \\
\hline Tamat SMA & 39 & 18.6 & $0.5-4.8$ \\
\hline Tamat SMP & 12 & 5.7 & \\
\hline Tamat SD & 5 & 2.4 & \\
\hline Tidak Sekolah & & & \\
\hline & & & \\
\hline
\end{tabular}

Berdasarkan Tabel 1. diketahui bahwa distribusi jenis kelamin dari total responden menunjukkan lebih banyak berjenis kelamin laki-laki yaitu sebesar 95.2\% sedangkan perempuan sebesar 4.8\% . Distribusi umur menunjukkan sebesar 22.9\% pada kategori usia 4554 tahun dan sebagian besar responden memiliki Pendidikan terakhir tamat SMA yaitu sebesar $58.6 \%$

Tabel 2.

Distribusi Pembelian Jenis Rokok dan Merek Rokok Responden di Kecamatan Medan Perjuangan

\begin{tabular}{lccc}
\hline \multicolumn{1}{c}{ Variabel } & Frekuensi & Persentase & 95\%CI \\
\hline Jenis Rokok & & & $64.8-77.1$ \\
\hline Rokok Filter & 149 & 71.0 & $22.9-35.2$ \\
\hline Rokok Kretek & 61 & 29.0 & \\
\hline Merek Rokok & & & $3.8-11.4$ \\
\hline Dji Sam Soe & 16 & 7.6 & $10.0-20.0$ \\
\hline Gudang Garam & 31 & 14.8 & \\
\hline
\end{tabular}




\begin{tabular}{lccc}
\hline Insta & 3 & 1.4 & $0.0-3.3$ \\
\hline LA & 1 & 0.5 & $0.0-1.4$ \\
\hline Magnum & 20 & 9.5 & $5.7-13.8$ \\
\hline Marlboro & 5 & 2.4 & $0.5-4.8$ \\
\hline Sampoerna & 29 & 13.8 & $9.0-19.0$ \\
\hline Surya & 89 & 42.4 & $35.2-48.6$ \\
\hline Lainnya & 16 & 7.6 & $4.3-11.4$ \\
\hline
\end{tabular}

Berdasarkan Tabel 2. diketahui bahwa distribusi pembelian jenis rokok dari total responden menunjukkan lebih banyak membeli rokok dengan jenis filter sebesar $71.0 \%$ dan distribusi pembelian merek rokok pada responden menunjukkan lebih banyak membeli rokok dengan merek surya sebesar $42.4 \%$.

Tabel 3.

Distribusi Paparan Iklan Rokok pada Responden di Kecamatan Medan Perjuangan

\begin{tabular}{|c|c|c|c|c|c|}
\hline Variabel & Mean & Median & Kategori & $\begin{array}{c}\text { Standar } \\
\text { Deviasi }\end{array}$ & $95 \% \mathrm{CI}$ \\
\hline \multicolumn{6}{|l|}{ Frekuensi } \\
\hline Media audio visual & 2.53 & 2.00 & Sedang & 2.112 & $2.25-2.81$ \\
\hline Media cetak & 3.60 & 3.00 & Tinggi & 2.229 & $3.32-3.91$ \\
\hline Media audio & 0.13 & 0.00 & Rendah & 0.577 & $0.06-0.22$ \\
\hline Total & 2.08 & 2.00 & Sedang & 1.776 & $0.13-3.60$ \\
\hline \multicolumn{6}{|l|}{ Intensitas } \\
\hline Alur cerita & 2.60 & 3.00 & Sedang & 1.202 & $2.44-2.77$ \\
\hline Jingle/tagline & 2.15 & 2.00 & Sedang & 1.147 & $1.99-2.32$ \\
\hline Isi pesan iklan & 3.15 & 3.00 & Tinggi & 0.955 & $3.02-3.28$ \\
\hline Total & 2.63 & 3.00 & Sedang & 0.500 & $2.15-3.15$ \\
\hline \multicolumn{6}{|l|}{ Durasi } \\
\hline Media audio visual & 2.14 & 2.00 & Sedang & 1.196 & $1.98-2.30$ \\
\hline Media cetak & 2.00 & 2.00 & Rendah & 1.105 & $1.86-2.14$ \\
\hline Media audio & 1.35 & 1.00 & Rendah & 0.852 & $1.23-1.47$ \\
\hline Total & 1.83 & 1.00 & Rendah & 0.421 & $1.35-2.14$ \\
\hline Total paparan & 2.10 & 2.00 & Sedang & 1.78 & $0.13-3.60$ \\
\hline
\end{tabular}

Berdasarkan tabel 3. diketahui bahwa rata-rata total paparan iklan rokok pada responden menunjukkan kategori sedang sebesar $2.10 \mathrm{kali} / \mathrm{hari}$ dengan paparan frekuensi menunjukkan kategori sedang sebesar 2.08 kali/hari, paparan intensitas menunjukkan kategori 
sedang sebesar $2.63 \mathrm{kali} / \mathrm{hari}$ dan paparan durasi menunjukkan kategori rendah sebesar 1.83 kali/hari.

Tabel 4.

Distribusi Minat Pembelian Rokok Responden di Kecamatan Medan Perjuangan

\begin{tabular}{lccccc}
\hline \multicolumn{1}{c}{ Variabel } & Mean & Median & Kategori & $\begin{array}{c}\text { Standar } \\
\text { Deviasi }\end{array}$ & 95\%CI \\
\hline Minat Transaksional & 1.75 & 1.00 & Rendah & 1.024 & $1.62-1.91$ \\
\hline Minat Referensial & 1.85 & 1.00 & Rendah & 1.147 & $1.70-2.01$ \\
\hline Minat Preferensial & 2.86 & 2.00 & Sedang & 1.227 & $2.16-3.56$ \\
\hline Minat Eksploratif & 2.45 & 2.00 & Sedang & 2.841 & $2.00-2.90$ \\
\hline Total Minat & $\mathbf{2 . 2 2}$ & $\mathbf{2 . 0 0}$ & Sedang & $\mathbf{2 . 1 2 1}$ & $\mathbf{1 . 7 5 - 2 . 8 6}$ \\
\hline
\end{tabular}

Berdasarkan tabel 4. diketahui bahwa rata-rata minat total pembelian rokok responden menunjukkan kategori sedang sebesar 2.22 kali/hari dengan rata-rata minat preferensial menunjukkan kategori sedang sebesar $2.86 \mathrm{kali} / \mathrm{hari}$ dan minat transaksional menunjukkan kategori rendah sebesar 1.75 kali/hari.

\section{PEMBAHASAN}

\section{Berdasarkan Jenis Kelamin}

Berdasarkan hasil penelitian didapatkan proporsi perokok berjenis kelamin laki-laki (95.2\%) lebih banyak dibandingkan dengan jumlah perokok berjenis kelamin perempuan (4.8\%). Hal ini sejalan dengan data Riskesdas (2018) yaitu proporsi perokok aktif paling banyak pada laki-laki dibandingkan dengan perempuan (47,5\% banding $1,1 \%)$. Hal tersebut sejalan dengan data yang disampaikan oleh WHO dan penelitian Wijayanti (2017) bagi laki laki merokok merupakan simbol kejantanan, kekuasaan dan kedewasaan.

Proporsi perokok berjenis kelamin perempuan mencapai $(4,8 \%)$ hal ini berarti perokok perempuan masih ditemukan pada masyarakat kecamatan medan perjuangan. Ditemukannya prilaku merokok pada perempuan bukan karena perempuan tidak mengetahui bahaya merokok tapi karena adanya pengaruh utama dari lingkungan pergaulan dan lingkungan keluarga. Lingkungan pergaulan menjadi pengaruh paling kuat terjadinya prilaku merokok pada perempuan karna keseharian seseorang selalu berinteraksi dengan teman temannya, selain itu prilaku merokok pada perempuan juga disebabkan karena melihat salah satu sosok anggota keluarganya yang merokok, sosok ini memiliki pengaruh yang kuat dan mempengaruhi perempuan untuk merokok (Lestari, 2011) 


\section{Berdasarkan Usia}

Hasil penelitian menunjukkan bahwa distribusi usia perokok paling banyak ialah pada kategori usia 45-54 tahun (22.9\%). Usia mempengaruhi prilaku merokok seseorang, hal ini sebabkan karena seseorang yang berusia diatas 16 tahun keatas sudah merasa lebih dewasa dan berhak melakukan apapun yang hendak mereka lakukan termasuk prilaku merokok (Binita, 2014). Namun, penelitian ini bertentangan dengan penelitian Global youth tobacco survey yang menyatakan bahwa prevalensi paling tinggi adalah remaja laki laki umur 13-14 sebanyak $67,7 \%$, hal tersebut menjadikan Indonesia menjadi negara dengan jumlah perokok terbanyak di asia tenggara. (Mirnawati et al., 2018)

\section{Berdasarkan Pendidikan Terakhir}

Dari hasil penelitian diketahui bahwa Pendidikan terakhir perokok yang paling banyak di Kecamatan Medan Perjuangan adalah tamat SMA yaitu sebesar 58.6\%. Penelitian ini sejalan dengan data Badan Pusat Statistik (BPS, 2016) yang menyatakan bahwa prevalensi perokok terbanyak berdasarkan tingkat pendidikan terakhir terdapat pada penduduk dengan lulusan Sekolah Menengah Atas (SMA) dimana tercatat sebagai status perokok aktif terbesar. Namun, penelitian ini bertentangan dengan penelitian yang dilakukan oleh (Handayani,2018), dimana tingkat pendidikan terakhir perokok terbanyak sebagai responden adalah pendidikan terakhir Sekolah Menengah Pertama (SMP) dengan persentase (42,6\%). Laki-laki yang berpendidikan rendah meningkatkan peluang untuk berperilaku merokok sebesar 3,57 kali dibandingakan laki-laki yang berpendidikan tinggi (Kuntz,et al. 2013).

\section{Jenis Rokok}

Hasil penelitian menunjukkan bahwa jenis rokok yang paling banyak dibeli adalah rokok filter $(71.0 \%)$ dibandingkan kretek $(29.0 \%)$. Hal ini sejalan dengan penelitian yang dilakukan Muliana (2013) yang menyatakan dari responden yang diteliti jenis rokok yang paling banyak dikondumsi adalah rokok filter (92,3\%) dibanding rokok kretek, hal tersebut dikarenakan rokok filter lebih ringan rasanya dan kadar nikotin pada rokok filter lebih sedikit dibanding rokok yang tidak memiliki filter. Adanya filter pada rokok filter membuat nikotin dalam asap rokok tertahan dalam filter namun tetap saja apapun jenis rokok masih tetap berbahaya untuk kesehatan. (Fidrianny I, 2004) 


\section{Merek Rokok}

Berdasarkan penelitian yang telah dilakukan merek rokok yang paling banyak dibeli responden adalah merek surya (42.4\%). Kebanyakan masyarakat setempat memilih merek surya menjadi pilihannya karena harganya yang tergolong murah bersikaran antara Rp 19.000

- Rp 25.000. Namun penelitian ini bertentangan dengan penelitian yang dilakukan Pramita (2019) pada masyarakat bumijo jestis yogyakarta yang menyatakan merek rokok yang paling banyak dikonsumsi masyarakat setempat adalah merek Gudang garam dengan harga berkisar antara Rp 18.000 - Rp 25.000 yang merupakan harga terjangkau untuk golongan menegah kebawah. Selain harga perbedaan minat beli terhadap merek rokok dapat terjadi karena selera konsumen rokok yang berbeda beda, perbedaan minat beli pada merek rokok bisa terjadi karna setiap merek rokok memberikan kepuasan yang berbeda beda sesuai dengan selera konsumen. (Noor, 2018)

\section{Paparan Iklan Rokok}

Berdasarkan penelitian rata rata total paparan iklan pada masyarakat Kecamatan Medan Perjuangan adalah sedang (2.10 kali/hari) hal ini dipengaruhi dari frekuensi, Intensitas dan durasi Iklan yang dilihat, dibaca dan didengar masyarakat setempat. (Well et al, 2000)

\section{Frekuensi}

Variabel frekuensi diukur dengan melihat keseringan responden melihat/membaca/mendengar iklan rokok melalui media audio visual, media audio maupun media cetak (Well et al, 2000). Berdasarkan hasil penelitian frekuensi responden menonton iklan rokok pada media audio visual menunjukkan kategori sedang (2.10 kali/hari) hal tersebut disebabkan karna tayangan iklan rokok di televisi yang dibatasi, iklan rokok hanya boleh diatayangkan diatas jam 21.30 WIB (UU No.32 Tahun 2002). Berdasarkan hasil penelitian pada media cetak paparan iklan rokok menunjukkan kategori tinggi (3.40 kali/hari) hal ini dikarenakan karena pada media cetak produsen rokok dapat mempromosikan rokok melalui banner, billboard, poster dan tembok publik yang membuat paparan iklan rokok semakin besar pada konsumen. (TCSC dan IAKMI, 2018) Berdasarkan hasil penelitian pada media audio paparan iklan rokok menunjukkan kategori rendah (0.13 kali/hari) hal ini dikarenakan jarangnya penggunan radio pada responden yang menyebabkan paparan iklan rokok melalui media audio cenderung rendah. Hal ini sejalan dengan penelitian TCSC bersama IAKMI (2018) yang menyatakan paparan iklan rokok melalui radio hanya mencapai 22,6\% pada usia dewasa sedangkan pada usia remaja hanya $17,4 \%$. 


\section{Intensitas}

Variabel Intensitas diukur dengan sejauh mana pengetahui responden mengetahui dan memahami alur cerita, jingle/tag line, dan isi pesan dari iklan rokok yang dilihat/dibaca/didengarkan responden. (Well et al, 2000). Berdasarkan penelitian diketahui bahwan pemahaman responden terhadap alur cerita iklan dan jingle/tag line menunjukkan kategori sedang dengan masing masing rata rata sebesar $2.60 \mathrm{kali} / \mathrm{hari}$ dan $2.15 \mathrm{kali} / \mathrm{hari}$ yang menunjukkan bahwa responden tidak terlalu memperhatikan alur cerita iklan rokok dan tidak terlalu mengingat slogan dari masing masing merek rokok yang mereka pakai tetapi responden memahami isi pesan dari iklan rokok dengan kategori tinggi (3.15 kali/perhari). Hal tersebut sejalan dengan penelitian Arianto (2018) yang menyatakan para perokok mengerti pesan iklan rokok yang bertujuan mempromosikan rokok walaupun iklan rokok tersebut tidak mengambarkan rokok, menceritakan seseorang yang merokok dan efek dari merokok itu sendiri.

\section{Durasi}

Variabel durasi diukur dengan menyimak iklan rokok dari awal hingga akhir ketika responden melihat/membaca/mendengar iklan rokok. (Well et al, 2000) Berdasarkan hasil penelitian diketahui responden menyimak iklan rokok pada media audio visual menunjukkan kategori sedang (2.14 kali/hari) dan responden menyimak pada media cetak dan media audio menunjukkan kategori rendah dengan masing masing sebesar $2.00 \mathrm{kali} / \mathrm{hari}$ dan $1.35 \mathrm{kali} / \mathrm{hari}$ yang berarti responden lebih tertarik pada iklan rokok yang ditampilkan di media audio visual dibandingkan pada media cetak dan media audio. Hal tersebut disebabkan karna pada media audio visual seperti televisi dan aplikasi media sosial dapat mengeluarkan suara dan gambar sekaligus. Sejalan dengan penelitian Harleyandi (2018) yang menyatakan bahwa iklan pada media audio kurang efektif karna media audio mulai ditinggalkan, konsumen juga lebih tertarik pada media audio visual karna dapat menampilkan suara dan gambar secara bersamaan.

\section{Minat Beli Konsumen Rokok}

Berdasarkan penelitian rata rata total minat beli konsumen rokok pada masyarakat Kecamatan Medan Perjuangan adalah sedang (2.22 kali/hari) hal ini dipengaruhi oleh minat transaksional, minat referensial, minat preferensial dan minat eksploratif (Ferdinand, 2006)

\section{Minat Transaksional}

Minat transaksional adalah kecenderungan seseorang untuk membeli produk, dalam hal ini konsumen telah memiliki minat untuk pembelian produk rokok yang diinginkan (Ferdinand, 2006). Berdasarkan penelitian diketahui bahwa rata rata minat transaksional respoden 
menunjukkan kategori rendah (1.75 Kali/hari) hal ini dikarenakan iklan rokok yang dilihat, dibaca maupun didengar tidak sepenuhnya mempengaruhi pilihan merek rokok yang akan dibeli karna responden sudah memiliki pilihan merek rokok utama masing masing. Hal tersebut sejalan dengan penelitian Widyastuti (2011) yang menunjukkan bahwa perokok memiliki merek rokok utama dan yang paling disukai seperti responden yang menyukai merek rokok sukun yang menyebabkan timbuk kesan baik terhadap rokok sukun dan memiliki kepercayaan tinggi terhadap kualitas rokok sukun.

\section{Minat Referensial}

Minat referensial adalah kecenderungan seseorang untuk menyarankan produk kepada orang lain dalam hal ini konsumen yang sudah memiliki minat untuk membeli akan menyarankan kepada orang terdekatnya untuk membeli produk rokok yang sama. (Ferdinand, 2006). Berdasarkan penelitian diketahui bahwa rata rata minat referensial responden menunjukkan kategori rendah (1.85 Kali/hari) hal ini dikarenakan kecenderungan menyarankan pilihan utama merek rokok pada responden rendah karna masing masing orang memiliki merek rokok utama sendiri dan memiliki selera masing-masing. Hal ini perkuat dengan penelitian Pramita (2018) yang menyatakan bahwa perokok memiliki selera dan tingkat konsumsi yang berbeda pada setiap merek rokok yang dikonsumsi sehingga membuat seseorang kesulitan untuk menyarankannya kepada orang lain.

\section{Minat Preferensial}

Minat preferensial adalah prilaku seseorang yang memiliki prioritas utama pada sebuah produk dalam hal ini konsumen telah memiliki prioritas merek utama untuk membeli rokok. Minat preferensial ini dapat diganti jika terjadi sesuatu dengan produk yang menjadi prioritas utama. (Ferdinand, 2006) Berdasarkan hasil penelitian diketahui bahwa rata-rata minat preferensial responden menunjukkan kategori sedang (2.86 kali/hari) hal ini dikarenakan responden sudah memiliki prioritas merek dalam membeli atau mengkonsumsi rokoksehingga akan kesulitan berpindah pada merek lain. Hal ini juga sejalan dengan penelitian Wijaya (2017) yang menyatakan merek menjadi pertimbangan responden dalam memilih rokok berdasarkan atas asosiasi selera, citra rasa dan kebanggaan.

\section{Minat Eskploratif}

Minat Eksploratif adalah prilaku seseorang yang selalu mencari informasi mengenai produk rokok yang diminatinya dan mencari informasi untuk mendukung sifat-sifat positif produk rokok tersebut. (Ferdinand, 2006) Berdasarkan hasil penelitian diketahui bahwa ratarata minat eksploratif responden menunjukkan kategori sedang (2.45 kali/hari) hal ini berarti responden masih mencari informasi positif terkait merek rokok yang diminatinya yang 
meningkatkan minat responden terhadap merek rokok yang diutamakan unruk dibeli. Hal ini bertentangan dengan penelitian Febriyantoro (2016) yang menyatakan kebanyakan perokok tidak mencari tau bahkan mengabaikan informasi yang diiklankan produsen rokok bahkan tidak menghiraukan pesan peringatan berbahaya merokok dan memilih untuk tetap merokok.

\section{KESIMPULAN}

Sebesar 95.2\% dari seluruh responden ialah berjenis kelamin laki-laki. Sebagian besar responden berusia 45-54 tahun sebesar 22.9\% dengan distribusi pendidikan terakhir menunjukkan 58.6\% merupakan tamat SMA. Responden paling banyak membeli rokok berjenis filter $71.0 \%$ dengan merek surya $42.4 \%$. Rata-rata total paparan iklan rokok pada responden menunjukkan kategori sedang sebesar $2.10 \mathrm{kali} / \mathrm{hari}$ dengan paparan frekuensi menunjukkan kategori sedang (2.08 kali/hari), paparan intensitas menunjukkan kategori sedang (2.63 kali/hari) dan paparan durasi menunjukkan kategori rendah (1.83 kali/hari). Ratarata minat total pembelian rokok pada responden menunjukkan kategori sedang sebesar 2.22 kali/hari dengan minat transaksional menunjukkan kategori rendah (1.75 kali/hari), minat referensial menunjukkan kategori rendah (1.85 kali/hari), minat preferensial menunjukkan kategori sedang (2.86 kali/hari) dan minat eksploratif menunjukkan kategori sedang (2.45 kali/hari).

\section{SARAN}

Bagi perokok agar tidak mudah terpengaruh dengan paparan iklan rokok yang dapat mempengaruhi minat beli terhadap rokok. Perokok aktif juga disarankan untuk dapat mengontrol pembelian rokok dengan memperhatikan aspek bahaya rokok bagi kesehatan. Bagi produsen rokok sebaiknya mendesain ulang iklan, produk dan penambahan gambar peringatan kesehatan agar iklan rokok yang dipaparkan lebih mementingkan aspek kesehatan. Bagi pemerintah khususnya pemerintah setempat untuk dapat menerapkan kebijakan terkait rokok sesuai kategori umur agar menekan perokok aktif khususnya para remaja yang rentan akan paparan iklan rokok. Bagi peneliti selanjutnya diharapkan dapat mengembangkan penelitian ini dengan mengaikat varibel penelitian yang ada dengan faktor kesehatan. 


\section{DAFTAR PUSTAKA}

Arianto, Yudi. 2018. Hubungan Antara Persepsi Iklan Rokok Media Elektronik dengan Perilaku Merokok pada Remaja. Skripsi. Fakultas Psikologi Universitas Mecubuana http://eprints.mercubuana yogya.ac.id/2562/8/COVER\%20DAN\%20LAMPIRAN\%20\%20BARU.pdf (Diakses pada tanggal 13 Februari 2021 Jam 0.16 WIB)

Bakti, Alam Kaloko. 2019. Survei Prevalensi Perokok di Kota Medan. Jurnal Pembangunan $\begin{array}{llllllll}\text { Perkotaan } & \text { Vol. } & 7 & \text { No. } & 1 & \text { (Januari } & - & \text { Juni }\end{array}$ ejpp.balitbang.pemkomedan.go.id/index.php/JPP/article/view/63 (Diakses pada tanggal 11 Februari Jam 10.56 WIB)

Beacukai.go.id Target penerimaan cukai 2019 sebesar $R p \quad 165,5$ Triliun https://www.beacukai.go.id/berita/target-penerimaan-cukai-2019-sebesar-rp165-5triliun.html (Diakses pada tanggal 11 Februari 2021)

Binita, A.M., Istiarti, V.T., dan Widagdo, L. 2016. Hubungan Persepsi Merokok dengan Tipe Perilaku Merokok pada Siswa SMK “ $X$ ” di Kota Semarang. Jurnal Kesehatan $\begin{array}{lllll}\text { Masyarakat } & \text { (e-Journal), } & 4(5): & 268 & -\end{array}$ https://ejournal3.undip.ac.id/index.php/jkm/article/view/14578 (Diakses pada tanggal 12 Februari 2021 Jam 14.15 WIB)

Bphn.go.id. 2012. Peraturan Pemerintah Republik Indonesia No 109 Tahun 2012 tentang pengamanan bahan yang mengandung zat adiktif berupa produk tembakau bagi kesehatan http://bphn.go.id/data/documents/12pp109.pdf (Diakses pada tanggal 11 Februari 2021 Jam 20:16 WIB)

BPS Kota Medan. 2018. Kota Medan dalam Angka. https://medankota.bps.go.id/publication/2020/05/20/4d88114085e598abae23c3e5/kot a-medan-dalam-angka-2020.html (Diakses pada tanggal 12 Februari 2021 Jam 12:27 WIB)

Desliyani Tri Wandita. 2020. Cukai rokok terhadap konsumsi rokok serta faktor-faktor yang mempengaruhi konsumsi rokok. Jurnal Pendidikan Ekonomi. Vol. 14 No. 1 (2020), 1907-9990 https://jurnal.unej.ac.id/index.php/JPE/article/view/16659 (Diakses pada tanggal 23 Februari Jam 17.00 WIB)

Febriyantoro, Tri Muhaamad. 2016. Pemikiran Irasional Para Perokok. Jurnal eksis (ekonomi dan bisnis) Vol. 11 No. 
https://ejournal.stiedewantara.ac.id/index.php/001/article/view/67 (Diakses pada tanggal 24 Februari Jam 19.31 WIB)

Ferdinand, Augusty., 2002. Pengembangan Minat Beli, Merek, Ekstensi. Semarang : Badan Penerbit Universitas Diponegoro. https://scholar.google.com/citations?user=qDCMh1AAAAAJ\&hl=ja (Diakses pada tangga; 13 Februari 2021 Jam 10.44)

Fidrianny I. 2004. Analisis Nikotin dalam Asap dan Filter Rokok. Skripsi. Bandung: Institut Teknologi Bandung https://core.ac.uk/download/pdf/230118041.pdf (Diakses pada tanggal 12 Februari 2021 Jam 19.25 WIB)

Handayani, Wahyu, Yetti Nurhayati, Maula Mar'atus Solikha. 2018. Hubungan Prilaku Merokok dengan Angka Kejadian Hipertensi di Desa Troboso Kecamatan Sambi Kabupaten Boyolali. Jurnal Universitas Kusuma Husada Surakarta http://digilib.ukh.ac.id/repo/disk1/37/01-gdl-wahyuhanda-1813-1-naskahp-i.pdf (Diakses pada tanggal 12 Februari 2021 Jam 15.46 WIB)

Harleyandi, Ridhwan Sudibyo. 2018. Pengaruh Terpaan Iklan Rokok Terhadap Minat Beli Konsumsen Rokok (Studi Kasus Pada Mahasiswa Fakultas Ekonomi Universitas Islam Indonesia. Skripsi. Fakultas Ekonomi Universitas Islam Indonesia. https://dspace.uii.ac.id/bitstream/handle/123456789/10141/SKRIPSI\%20\%20RIDHWAN\%20HARLEYANDI\%20S.\%20\%2814311011\%29.pdf?sequence=2 \&isAllowed=y (Diakses pada tanggal 24 Februari 2020 Jam 19:20 WIB)

Ika Rahma Ginting \& Rizky Maulana. 2020. Dampak kebiasaan merokok pada pengeluaran rumah tangga. Jurnal Kebijakan Kesehatan Indonesia : JKKI. Vol. 09 No. 02 (2020) https://jurnal.ugm.ac.id/jkki/article/view/55879 (Diakses pada tanggal 13 Februari 2021 Jam 10.20 WIB)

Kuntz, Harold, 2013. Making The Most of Herbal and Botanical Ingrediens. Http://www.foofproductdesign.com /Archive/2013/0300ap.html. (Diakses pada tanggal 12 Februari 2021 Jam 18:35 WIB)

Lestari, Yuni, Argyo Demartoto. 2011. Perempuan dan Rokok (Kajian Sosiologi Kesehatan Terhadap Perilaku Kesehatan Reproduksi Perempuan Perokok di Kota Surakarta). $\begin{array}{lllllll}\text { Jurnal Promosi Kesehatan } & \text { Vol. } 6 & \text { No. } & 1 & \text { Januari }\end{array}$ https://ejournal.undip.ac.id/index.php/jpki/article/view/18769 (Diakses pada tanggal 24 Februari 1:14 WIB)

Mirnawati, Nurfitriani, Febriana Maya Zulfiarini, Widya Hary Cahyati. 2018. Perilaku rokok remaja umur 13-14 tahun. Jurnal HIGEIA Vol. 2 No. 3 
https://journal.unnes.ac.id/sju/index.php/higeia/article/view/26761 (Diakses pada tanggal 12 Februari 2021 Jam 19.25 WIB)

Muliyana, Dwi, Ida leida, M. Thaha. 2013. Faktor yang berhubungan dengan Tindakan Merokok pada Mahasiswa Universitas Islam Hasnuddin Makassar. Jurnal MKMI Juni 2013 hal 109-119 (https://journal.unhas.ac.id/index.php/mkmi/article/view/446\#: :text=Kesimpulannya \%20adalah\%20faktor\%20pengetahuan $\% 2 \mathrm{C} \% 20$ sikap,memiliki $\% 20$ hubungan $\% 20 \mathrm{den}$ gan\%20tindakan\%20merokok. (Diakses pada tanggal 12 Februari 2021 Jam 19.01 WIB)

Nielsen.com. 2019. Belanja iklan 2019 ditutup dengan tren positif https://www.nielsen.com/id/id/press-releases/2020/belanja-iklan-2019-ditutupdengan-tren-positif/ (Diakses pada tanggal 11 Februari 2021 Jam 23.01 WIB)

Noor, Ichsan Fahmi. 2018. Gambaran tingkat pengetahuan siswa sekolah dasar tentang bahaya rokok di SDN. 018 Samarinda. Karya tulis Ilmiah Fakultas Ilmu Kesehatan dan Farmasi Universitas Muhammadiyah Kalimantan Timur https://dspace.umkt.ac.id/bitstream/handle/463.2017/594/Ichsan\%20Noor\%20Fahmi-. pdf?sequence $=2$ (Diakses pada tanggal 24 Februari 2021 Jam 19:11 WIB)

P2ptm.kemkes.go.id. Apa saja kandungan di dalam sebatang rokok? http://p2ptm.kemkes.go.id/infographic-p2ptm/penyakit-paru-kronik/apa-sajakandungan-di-dalam-sebatang-rokok-2 (Diakses pada tanggal 11 Februari 2021 Jam $\underline{16.02 \mathrm{WIB})}$

P2ptm.kemkes.go.id. WHO : 40\% Lebih Perokok di Seluruh Dunia Meninggal karena Penyakit Paru-Paru http://www.p2ptm.kemkes.go.id/artikel-sehat/who-40-lebih-perokok-di$\underline{\text { seluruh-dunia-meninggal-karena-penyakit-paru-paru }}$ (Diakses pada tanggal 11 Februari 2021 Jam 15.11 WIB)

Pemkomedan.go.id. 2014. Peraturan Daerah Kota Medan Nomor 3 Tahun 2014 tentang Kawasan tanpa rokok https://pemkomedan.go.id/file/PERDA(KAWASAN\%20TANPA\%20ROKOK).pdf (Diakses pada tanggal 11 Februari 2021 Jam 20:32)

Pramita, Cicilia Puspa Astri. 2019. Analisis Perilaku Merokok pada Perokok di Bumijo Jetis Yogyakarta. Skripsi. Fakultas Keguruan dan Ilmu Pendidikan Universitas Sanata Dharma Yogyakarta http://repository.usd.ac.id/35374/2/131324012_full.pdf (Diakses pada tanggal 12 Februari 2021 Jam 20.52 WIB) 
Tcsc-indonesia.org. Tobacco Control Suport Center Ikatan Ahli Kesehatan Masyarakat Indonesia http://www.tcsc-indonesia.org/beranda/ (Diakses pada tanggal 11 Februari 2021 Jam 15:28 WIB)

Tobacco Control Support Center dan IAKMI. 2018. Paparan Iklan Rokok, Promosi, dan Sponsor Rokok di Indonesia. Laporan Penelitian http://www.tcsc-indonesia.org/wpcontent/uploads/2018/10/Hasil-Studi-Paparan-Iklan-Promosi-dan-Sponsor-Rokok-diIndonesia_TCSC-IAKMI.pdf (Diakses pada tanggal 12 Februari 2021 Jam 23.55)

Warahmah, Sakinah. 2018. Pengaruh Slogan Bahaya Merokok Yang Tertera Pada Bungkus Rokok Terhadap Minat Beli Masyarakat. Skripsi. Fakultas Ekonomi dan Bisnis Islam $\begin{array}{llll}\text { Universitas } & \text { Islam } & \text { Negeri } & \text { Sumatera }\end{array}$ http://repository.uinsu.ac.id/5107/1/SAKINAH\%20WARAHMAH.pdf (Diakses pada tanggal 11 Februari Jam 20.45 WIB)

Wells, William., John Burnett, Sandra Moriarty. 2000. Advertising Pririnciples And Practice, Five Edition, New Jersey : Prentice-Hall International. http://lib.ui.ac.id/detail.jsp?id=20232875 (Diakses pada tanggal 13 Februari 2021 Jam 12.13 WIB)

Widyastuti, Dinny. 2011. Analisis Pengaruh Efek Komunitas, Kekhasan Produk, Citra Merek Kepada Sikap Merek dan Implikasinya Terhadap Minat Membeli Ulang. Skripsi. Universitas Diponegoro http://eprints.undip.ac.id/29305/1/jurnal.pdf (Diakses pada tanggal 13 Februari 2021 Jam 10.15)

Wijayanti, Erlina, Citra Dewi, Rifqatussa'adah. 2017. Faktor faktor yang berhubungan dengan prilaku merokok pada remaja kampung bojo rajawele, jatimakmur, Bekasi. Jurnal global medical and health communication.

https://www.researchgate.net/publication/322155182_Faktorfaktor_yang_Berhubunga $\underline{\text { n_dengan_Perilaku_Merokok_pada_Remaja_Kampung_Bojong_Rawalele Jatimakm }}$ ur_Bekasi (Diakses pada tanggal 12 Februari 2021 Jam 15.23 WIB)

Wijaya, Tony, Nurhadi, Andreas Mahendro Kuncoro. 2017. Studi Eksplorasi Perilaku Konsumsi Rokok : Perpekstif Motif, Merek dan Iklan Rokok. Jurnal Economia Vol. 13 No. 2 Oktober 2017

http://staffnew.uny.ac.id/upload/197907162014041001/penelitian/2017-Economia.pdf (Diakses pada tanggal 13 Februari 2021 Jam 12.00 WIB) 